ISSN: 2224-0616

Int. J. Agril. Res. Innov. Tech. 11(1): 69-73, June 2021

DOI: https://doi.org/10.3329/ijarit.v11i1.54468
OPEN $\%$ ACCESS

Available online at https://ijarit.webs.com https://www.banglajol.info/index.php/IJARIT

\title{
Production and profitability of small scale broiler farming in selected areas of Dinajpur district, Bangladesh
}

\author{
G. Rabbani ${ }^{*}$ and B. Ahmad ${ }^{2}$ \\ Received 10 March 2021, Revised 28 April 2021, Accepted 23 June 2021, Published online 30 June 2021
}

\begin{abstract}
A B S T R A C T
This study focuses on the production and profitability of the broiler farming by using CobbDouglas production function and Benefit-Cost analysis. For this purpose, data were collected from 50 broiler farmers living in Birol and Sadar upazila of Dinajpur district in 2020. The result revealed that involvement in broiler production seems to be profitable for the small-scale broiler farmers for the study areas notifying by net return as Tk. 6681 with a benefit-cost ratio greater than one, whereas the gross return was Tk.193367. The net return over the total cost is 0.075 . The production function resulted that feed, medicines and human labor had significant positive effect on production of broiler whereas only rental cost had negative effect. Training had a highly significant $(\mathrm{p}<0.01)$ positive effect on production of broiler. Therefore, it can be recommended that training and proper use of drugs and medicine should be encouraged because of their significant impact. Government and NGOs should also arrange more training for improving broiler production in Bangladesh.
\end{abstract}

Keywords: Benefit-cost analysis, Broiler, Broiler production, Market price, Profitability.

${ }^{l}$ Department of Economics, Hajee Mohammad Danesh Science and Technology University, Dinajpur, Bangladesh.

${ }^{2}$ MSS Student, Department of Economics, Hajee Mohammad Danesh Science and Technology University, Dinajpur, Bangladesh.

*Corresponding author’s email:drgolamrabbani65@gmail.com (G. Rabbani)

Cite this article as: Rabbani, G. and Ahmad, B. 2021. Production and profitability of small scale broiler farming in selected areas of Dinajpur district, Bangladesh. Int. J. Agril. Res. Innov. Tech. 11(1): 69-73. https://doi.org/10.3329/ijarit.v11i1.54468

\section{Introduction}

Agriculture is considered as one of the most important wheels of an economy especially for developing countries like Bangladesh. The happiness can be observed as a tree where the agriculture can be seen as the root, commerce and industry are its branches and leaves and if this is detached then the tree will die (Paddy, 2001). In Bangladesh, poultry production is done for two purposes: one for meat and the other is for the production of egg. More than half of the people of this country are directly or indirectly involved in the agriculture and the livestock farming. This involvement creates the employment opportunities for the young generation. As a result, increase in the livestock production satisfies the domestic demand of the meat and nutrition. On the contrary, this participation of youth in livestock farming and raising production promotes economic growth as well as reduces poverty in both urban and rural areas (Hamid et al., 2017). Coping with the domestic demand by poultry specially broilers for meat and the layer for the egg plays vital role and cannot be ignored (Anas, 2015). Several improved varieties of poultry are rearing in both rural and urban areas including free range, semi intensive and intensive range. This type of rearing method is mainly determined by the type of birds to be produced, available resources and the local demand for that particular kind (Buragohain et al., 2007; Pathakand Nath, 2013). However, poultry industry in Bangladesh is now reaching a promising place, which is also contributing to the country's growth of Gross Domestic Product (GDP) (Raha, 2013) .The first wave of changing poultry industry of Bangladesh, was seen in 1934 by the government intervention. The wave of poultry industry lasted until near to 1960. After 1960, the commercial production of meat and eggs began in Bangladesh (Kabir, 2005; Rahman et al., 2017). Cobb 505, Ross 308 and Indian River Meat are the most common type of farmed broiler chicken in Bangladesh (Rahman et al., 2017). These are not produced only for the meat but for having change in economic condition by raising saving, income and reducing unemployment. Mozumdar et al. (2009) conducted a study on broiler farming in sadar upazila of Mymensingh. He found that broiler farmers have an annual employment opportunity of 320 person-days. In addition, the income of them has increased ranging between Tk.3065 and Tk.6100 after starting broiler farming. 
Eggs and Hens Limited first started privately commercial production of poultry in 1964 at Gazipur (Akter, 2013). Training can play a vital role in broiler production. Center (2004) found that trained farmers are more efficient and profitable compared to those who have no training on broiler production. Broiler farming has been recognized as profitable one as a whole in the context of Bangladesh (Begum, 2005; Chowdhury and Chowdhury, 2015; Islam et al., 2016). In broiler production medicine and vaccine has fruitful implication to have better and larger quantity of production. Sultana et al. (2012) found that about $90 \%$ broiler farmers take vaccine where the average weight of $78 \%$ broiler is $1.5 \mathrm{~kg}$ and the rest $22 \%$ has $1.8 \mathrm{~kg}$. Average age of the broiler birds to be sold as 30-33 days old with costing of 90-95 taka whereas each matured boiler is sold at Tk. 110-115. However several problems are found in broiler farming such as high price of feed, lack of capital, marketing facility problems, lack of credit facilities, low price of selling chickens and so on (Islam et al., 2016; Chowdhury and Chowdhury, 2015; Sultana et al.,2012;Kawsaret al., 2013). This study signifies profitability of broiler farming in the selected areas of Dinajpur district especially in Sadar and Birol upazila renowned for poultry production in this district.

\section{Materials and Methods}

\section{Study areas and data collection}

Mainly primary data were used in this study. This present study is conducted in two upazilas of Dinajpur district, which are Dinajpur sadar and Biral where about $84 \%$ of data were collected from several villages of Biral and the rest were collected from Dinajpur sadar. This was happened due to large sample availability in Biral. It was impossible to interview all the Broiler farmers in the sample areas due to limitations of time and resources. For this reason, reasonable sizes of sample farmers were chosen which could at least satisfy the objectives set for the study. A multistage sampling procedure was followed to select broiler-farming areas. In the first stage, one broiler-growing district (Dinajpur) with two Upazilas (Dinajpur Sadar and Biral) was selected purposively. In the second stage, two villages from each Upazila were selected randomly. Finally, fifty-one sample broiler farms were visited during November 2020 to collect data for materializing our objectives.

\section{Production function}

Cobb-Dauglas production function was used to analyze the production of broiler. The functional form is as below:

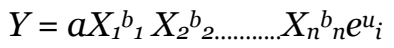

Where,

$Y=$ Dependent variable; $X_{1} \ldots \ldots \ldots . . . X_{n}=$ Explanatory variable; $a=$ Constant; $b_{1}$, $b_{2} \ldots \ldots \ldots \ldots . . . . b_{n}=$ Coefficient of relevant variables; $u_{i}=$ Stochastic of disturbance term, $\mathrm{e}=$ Base of natural logarithm.

The function is linearized by transforming it into the following logarithmic (double log) form

$\operatorname{Ln} Y_{i}=\beta_{0}+\beta_{1} \operatorname{Ln} X_{1}+\beta_{2} \operatorname{Ln} X_{2}+\beta_{3} \operatorname{Ln} X_{3}+\beta_{4} \operatorname{Ln}$ $\mathrm{X}_{4}+\beta_{5} \operatorname{Ln} \mathrm{X}_{5}+\beta_{6} \operatorname{Ln} \mathrm{X}_{6}+\mathrm{u}_{\mathrm{i}}$

Where,

Ln = Natural logarithm; $Y_{i}=$ Broilers produced for the i-th farm measured in number of chicken (per shed); $X_{1}=$ Chickens bought (Number/per shed); $\mathrm{X}_{2}=$ Human labor used (man-days/per shed); $\mathrm{X}_{3}=$ Feed used (Kg/per shed); $\mathrm{X}_{4}=$ Rental cost measured in taka (per shed); $\mathrm{X}_{5}=$ Training received measured as dummy variable: 1 for 'yes' and $\mathrm{o}$ for 'otherwise'; $\mathrm{X}_{6}=$ Drugs and medicine cost (Tk/per shed).

\section{Profitability analysis}

Gross return can be calculated as the product of output to the price of each unit as calculated by Sujan et al. (2017):

$\mathrm{GR}_{\mathrm{i}}=\sum_{\mathrm{i}=1}^{\mathrm{n}} \mathrm{Q}_{\mathrm{i}} \mathrm{P}_{\mathrm{i}}+\sum_{\mathrm{i}=1}^{\mathrm{n}} \mathrm{B}_{\mathrm{j}}$

Where, $\mathrm{GR}_{\mathrm{i}}=$ Gross return from ith product (Tk/per shed); $\mathrm{Q}_{\mathrm{i}}=$ Quantity of the ith main product $(\mathrm{Kg} /$ per shed $) ; \mathrm{P}_{\mathrm{i}}=$ Average price of the ith main product $(\mathrm{Tk} / \mathrm{kg}) ; \mathrm{B}_{\mathrm{j}}=$ Estimated value of the jth by-product (Tk/ per shed);

Gross margin is the amount of total revenue after subtracting it from the total variable cost and calculated as:

$\mathrm{GM}=\mathrm{TR}-\mathrm{TVC}$

Where, $\mathrm{GM}=$ Gross Margin; TR = Total Return; and TVC $=$ Total Variable Cost.

Net return is the amount of money received from an investment or a company's activities after all costs have been paid out. It was calculated using the following formula as used by Bala et al. (2020):

$\Pi=\sum \mathrm{P}_{\mathrm{m}} \mathrm{Q}_{\mathrm{m}}-\Sigma\left(\mathrm{P}_{\mathrm{xi}} \mathrm{X}_{\mathrm{i}}\right)-\mathrm{TFC}$

Where, $\Pi=$ Net return (Tk/ per shed); $\mathrm{P}_{\mathrm{m}}=$ Per unit price of produce $(\mathrm{Tk} / \mathrm{kg}) ; \mathrm{Q}_{\mathrm{m}}=$ Quantity of the production per shed $(\mathrm{Kg}) ; \mathrm{P}_{\mathrm{xi}}=$ Per unit price of $i$ th inputs (Tk); $X_{i}=$ Quantity of the $i$ th inputs per shed (kg); TFC = Total fixed cost (Tk); and $\mathrm{i}=$ $1,2,3, \ldots \ldots \ldots . . . . . . ., n$ ( number of inputs).

Benefit-Cost analysis is familiar to profitability analysis in agricultural economics. This can be calculated as the ratio of the gross return and gross cost (Islam et al., 2017; Sujan et al., 2021).

$$
B C R=\frac{\text { Gross Benefit }}{\text { Gross Cost }}
$$




\section{Results and Discussion}

\section{Estimated result of production function}

The result of stochastic production function is shown in Table 1. Therefore, the coefficients of variables $\mathrm{X}_{1}, \mathrm{X}_{2}$ and $\mathrm{X}_{3}$ are positively correlated with the broiler production at 5\% level of significance. However, coefficients of feed used $\left(\mathrm{X}_{3}\right)$ and ownership pattern $\left(\mathrm{X}_{5}\right)$ are also positively related with the output at $1 \%$ level of significance. This is similar to the study of Ohajianya et al. (2013), Bethel et al. (2016) and Ike (2011). This result is also inverse of Adesiyan (2014). Only rental cost is identified as negatively correlated with broiler production, which is significant at $10 \%$ level indicating that an increase of the rental cost will cause to fall in the production and vice versa.

Table 1. Estimated result of production function.

\begin{tabular}{|lccc|}
\hline Variables description & Coefficients & Standard Error & $\begin{array}{c}\text { Significance Level } \\
\text { (p values) }\end{array}$ \\
\hline Constant & 0.356 & 0.919 & 0.698 \\
\hline $\mathrm{X}_{1}$ (Chicks bought per shed) & 0.102 & 0.045 & $0.024^{* *}$ \\
\hline $\mathrm{X}_{2}$ (Human labour/per shed) & 0.183 & 0.086 & $0.035^{* *}$ \\
\hline $\mathrm{X}_{3}$ (Feed used/per shed) & 0.616 & 0.106 & $0.000^{* * *}$ \\
\hline $\mathrm{X}_{4}$ (Rental cost/per shed) & -0.025 & 0.015 & $0.088^{*}$ \\
\hline $\mathrm{X}_{5}$ (Training received) & 0.194 & 0.282 & $0.000^{* * *}$ \\
\hline $\begin{array}{l}\mathrm{X}_{6} \text { (Drugs and medicine } \\
\text { cost/per shed) }\end{array}$ & 0.136 & 0.068 & $0.045^{* *}$ \\
\hline Sigma-squared( $\left.\sigma_{\mathrm{s}}{ }^{*}\right)$ & 0.831 & & \\
\hline Gamma ( $\gamma)$ & 0.51 & & \\
\hline Lambda & 0.230 & & \\
\hline Log likelihood & -66.819 & & \\
\hline Number of observation & 50.00 & & \\
\hline
\end{tabular}

Note: ${ }^{*},{ }^{* *}$ and ${ }^{* * *}$ refers to $10 \%, 5 \%$ and $1 \%$ significance level, respectively.

\section{Profitability analysis}

Table 2 shows the average input cost per shed production of broiler in the sampled areas. The total variable input is 4272 in quantity. Total variable cost of broiler production is as Tk. 168272. Total unit cost of variable inputs is Tk. 1444 .

Table 2. Per shed average input cost for broiler farming.

\begin{tabular}{|c|c|c|c|c|}
\hline \multirow[t]{11}{*}{$\begin{array}{l}\text { Sl. } \\
\text { No. }\end{array}$} & Inputs of Production & Quantity & $\begin{array}{l}\text { Unit Cost } \\
\text { (Tk.) }\end{array}$ & $\begin{array}{l}\text { Total Cost } \\
\text { (Tk.) }\end{array}$ \\
\hline & Feed (kg) & 2150 & 43 & 92450 \\
\hline & Chicks (Per shed) & 1875 & 24 & 45000 \\
\hline & Medicine and drugs(doges) & 37 & 162 & 5994 \\
\hline & Labour (man/days) & 35 & 250 & 8750 \\
\hline & Transportation (per shed) & 4 & 408 & 1632 \\
\hline & Drinker (No.) & 75 & 78 & 5850 \\
\hline & Feeder (pieces) & 86 & 90 & 7740 \\
\hline & Protecting cloth (No.) & 2 & 350 & 700 \\
\hline & Gloves (Pair) & 4 & 27 & 108 \\
\hline & Mask (No.) & 4 & 12 & 48 \\
\hline \multicolumn{2}{|c|}{ Total variable cost } & 4272 & 1444 & 168272 \\
\hline \multirow[t]{6}{*}{ B. } & Fixed cost & & & \\
\hline & Depreciation of farm implements & - & - & 465 \\
\hline & Rental value (per shed) & - & - & 3800 \\
\hline & Electricity charges (per shed) & - & - & 3140 \\
\hline & Machinery cost & - & - & 3600 \\
\hline & Interest on operating cost & - & - & 527 \\
\hline \multicolumn{2}{|c|}{ Total fixed cost } & - & - & 11532 \\
\hline & Total Cost $(\mathrm{A}+\mathrm{B})$ & 4272 & 1444 & 179804 \\
\hline
\end{tabular}


Total fixed cost for the small-scale broiler farmers was Tk. 4272 in quantity size expressing Tk. 179804. This cost may also higher due to sudden outbreak of problems such as bird flu, Corona virus or any other virus that affects both livestock and human beings.

Table 3. Per shed yield, cost and profitability of broiler farming.

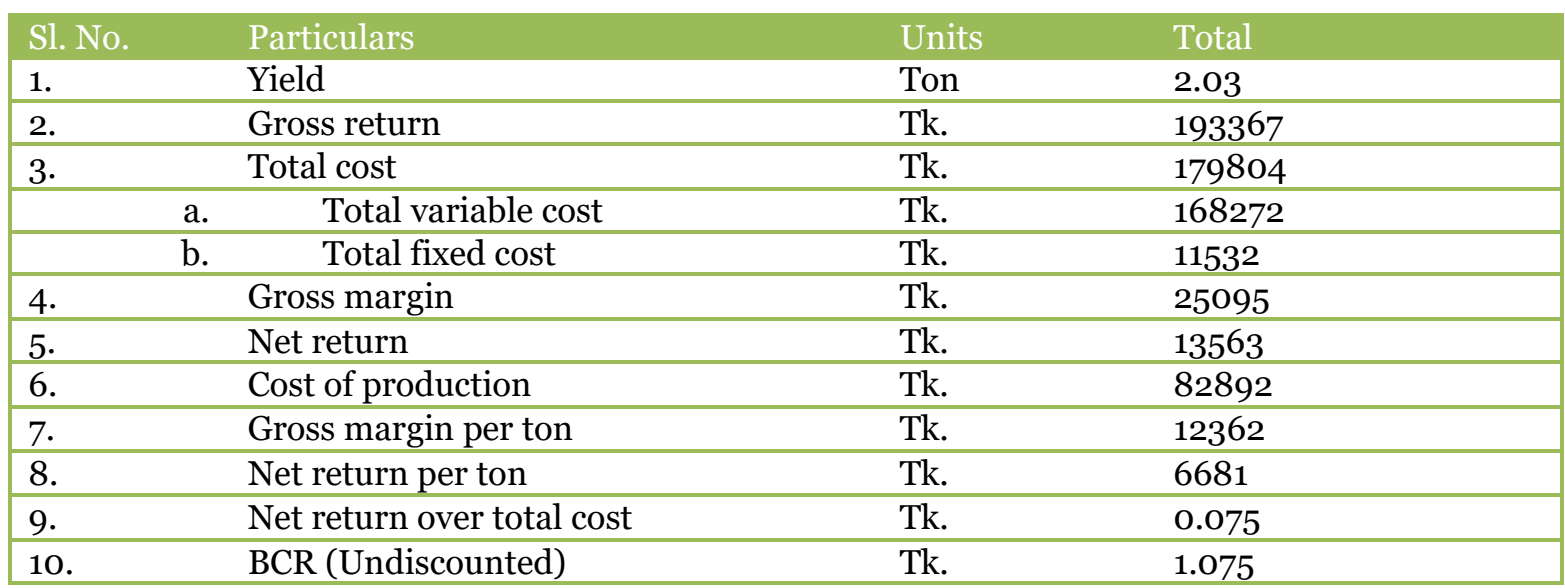

Table3 reveals that the average broiler yield per shed was about 2.03 ton. The average gross return was Tk. 193367 per shed. The average gross margin was Tk.12362. The average net return from broiler production was Tk.6681 per ton. However, net return wasTk.13563per shed. Production costs per ton were Tk. 82892 (Table3). Net return over each taka cost in broiler production was Tk. 0.075. However, from the Table3, it was observed that the overall undiscounted BCR considering total cost was 1.075 indicating profitable farming. This is similar to the studies of Mozumdar et al. (2009), Sultana et al. (2012), Rana et al. (2012) and Islam et al. (2017).

\section{Conclusion}

Broiler farming can be an alternative way to promote self-employment for Bangladesh whose has a huge young population to convert from unemployed to employed persons. This also reveals that the broiler farmers living in Dinajpur district are also profitable in their farming that is indicated by net return of Tk.13563 per shed production where net return over the total cost was indicated at 0.075 . However, this study is limited to Dinajpur district and confined with only broiler farming for meat. This study can be further enhanced by studying for all categories of poultry for meat and the larger areas can be considered.

\section{Acknowledgement}

This study was carried out by the grant of Institute of Research \& Technology (IRT), Hajee Mohammad Danesh Science \& Technology University, Dinajpur-5200, Bangladesh.

\section{References}

Adesiyan, O.I. 2014. Technical efficiency of poultry production in Afijio Local Government Area of Oyo State, Nigeria. Dev. Country Stud. 4(20): 74-79.

Akter, A. 2013. Financial profitability and resource use efficiency of broiler farming in a selected area of Bangladesh. Doctoral dissertation, Dept. of Agricultural Economics. Sher-E-Bangla Agricultural University. p.19.

Anas, A.Z.M. 2015. Branded meat sector grows as middle class demand rises. Published in Financial Express on $1^{\text {st }}$ February 2015.

Bala, H., Ghosh, A.K., Kazal, M.M.H., Rahman, M.S., Sultana, M. and Sujan, M.H.K. 2020. Floating gardening in Bangladesh: a sustainable income generating activity in wetland areas. Int. J. Agril. Res. Innov. Tech. 10(1): 87-93.

https://doi.org/10.3329/ijarit.v10i1.48098.

Begum, I.A. 2005. Vertically integrated contract and independent poultry farming system in Bangladesh: a profitability analysis. Livestock Res. Rural Dev. 17(8): 23-24.

Bethel, E., Fani, D.R. and Odufa, E.M. 2016. Analysis of technical efficiency of poultry farmers in Cross River State, Nigeria. Int. J. Res. Stud. Agril. Sci. 2(4): 40-45.

Buragohain, R., Ghosh, M.K., Ahmed, F.A., Pathak, P.K. and Bhattacharya, M. 2007. Growth performance of Vanaraja birds in high altitude areas of Arunachal Pradesh. Indian Vet. J. 84: 302-303.

Center, Y.T. 2004.Efficiency of trained farmers on the productivity of broilers in a selected area of Bangladesh. Int. J. Poultry Sci. 3(8): 503-506.https://doi.org/10.3923/ijps.2004.503.506

Chowdhury, M.S.R.C. and Chowdhury, M.M. 2015. Profitability analysis of poultry farming in Bangladesh: A case study on Trishal upazilla in Mymensingh district. Dev. Country Stud. 5(19).107-114. 
Hamid, M.A., Rahman, M.A., Ahmed, S. and Hossain, K.M. 2017. Status of poultry industry in Bangladesh and the role of private sector for its development. Asian J. Poultry Sci. 11(1): 1-13. https://doi.org/10.3923/ajpsaj.2017.1.13

Ike, P.C. 2011. Resource use and technical efficiency of small-scale poultry farmers in Enugu state, Nigeria: A stochastic frontier analysis. Int. J. Poultry Sci. 10(11): 895-898.

Islam, F., Akther, B., Khatun, A., Harun-OrRashid, M. and Hossain, M.S. 2016. Profitable broiler farming at the villages of Khulna district in Bangladesh. J. Biosci. Agric. Res. 8(1): 678-684. https://doi.org/10.18801/jbar.080116.80

Islam, M.Z., Begum, R., Sharmin, S. and Khan, A. 2017. Profitability and productivity of rice production in selected coastal area of Satkhira district in Bangladesh. Int. J. Bus. Mang. Social Res. 3(1): 148-153.

Kabir, S.S.K. 2005. Poultry in Bangladesh: Awaiting the awakening. pp. 14-16. In: Proceeding of $4^{\text {th }}$ International Poultry Show and Seminar, from February (Vol. 28). Dhaka, Bangladesh.

Kawsar, M.H., Chowdhury, S.D., Raha, S.K. and Hossain, M.M. 2013. An analysis of factors affecting the profitability of small-scale broiler farming in Bangladesh. World's Poultry Sci.J. 69(3): 676-686. https://doi.org/10.1017/So043933913000676

Mozumdar, L., Farid, K.S., Ahmed, J.U. and Rahman, M.W. 2009. Broiler farming: An approach to improve rural livelihood. $J$. Bangladesh Agril. Univ. 7(2): 395-402.

Ohajianya, D.O., Mgbada, J.U., Onu, P.N., Enyia, C.O., Henri-Ukoha, A., Ben-Chendo, N.G. and Godson-Ibeji, C.C. 2013. Technical and economic efficiencies in poultry production in Imo State, Nigeria. J. Exptl. Agric. Int. 3(4): 927-938.
Paddy, A. 2001. Poultry Business Heads for Doom. Nigeria Agricultural Magazine, Nov/Dec. p. 130.

Pathak, P.K. and Nath, B.G. 2013. Rural poultry farming with improved breed of backyard chicken. J. World's Poultry Res. 3(1): 24-27.

Raha, S.K. 2013. Poultry industry in Bangladesh: ample opportunities for improvement. pp. 13-19. In: Proceedings of the seminar, $8^{\text {th }}$ International Poultry Show and Seminar. World's Poultry Science Association, Bangladesh Branch.

Rahman, M.S., Jang, D.H. and Yu, C.J. 2017. Poultry industry of Bangladesh: entering a new phase. Korean J. Agril. Sci. 44(2): 272282. https://doi.org/10.7744/kjoas.20170027

Rana, K.A.M., Rahman, M.S. and Sattar, M.N. 2012. Profitability of small-scale broiler production in some selected areas of Mymensingh. Prog. Agric. 23(1-2): 101-109.

Sultana, F., Khatun, H. and Islam, A. 2012. Small scale broiler farming at Santhia upazilla of Pabna District of Bangladesh. Bangladesh $J$. Animal Sci. 41(2): 116-119. https://doi.org/10.3329/bjas.v41i2.14129

Sujan, H.K., Islam, F., Kazal, M.H. and Mondal, R.K. 2017. Profitability and resource use efficiency of potato cultivation in Munshiganj district of Bangladesh. SAARC J. Agric. 15(2): 193-206. https://doi.org/10.3329/sja.v15i2.35151

Sujan, M.H.K., Islam, F., Azad, M.J. and Rayhan, S.J. 2017. Financial profitability and resource use efficiency of boro rice cultivation in some selected area of Bangladesh. African J. Agric. Res. 12(29): 2404-2411. https://doi.org/10.5897/AJAR2017.12443

Sujan, M.H.K., Kazal, M.M.H., Ali, M.S. and Rahman, M.S. 2021. Cost-benefit analysis of mud crab fattening in coastal areas of Bangladesh. Aqua. Reports. 19: 100612. https://doi.org/10.1016/j.aqrep.2021.100612 